\title{
PROVENANCE OF HEAVY-MINERALS IN THE PIRANHAS-AÇU RIVER, NORTHEASTERN BRAZIL
}

\section{MARCIA GOMES DA SILVA AND HELENICE VITAL}

\begin{abstract}
Clino-amphibole, epidote, garnet, sillimanite, tourmaline, staurolite, andalusite, zircon, rutile, augite, ilmenite, hematite and magnetite are the heavy-minerals recorded in the Piranhas-Acu River. Six assemblages were identified: (i) Garnet-hornblende-tourmaline with sillimanite, when cutting rocks of the Seridó Formation; (ii) Hornblende-garnet-zircon, when crossing rocks of the Caicó gneiss-migmatite Complex; (Hi) Hornblende-zircon-epidote-staurolite, when in rocks of the Jucurutu Formation; (iv) Hornblende-zircon-epidote, when rocks of the Açu Formation; (v) Hornblende-zircon-staurolite, when the lowermost Agu River channel cuts limestones of the Jandaira Formation, and (vi) Zircon-tourmaline-staurolite in the Açu River mouth (Cenozoic rocks) where coastal dynamics dominate. Mineral ratios that reflect differences in grain shape, density, and selective chemical decomposition were used to isolate the effects of "source" and "process" as controls of mineral variability. The reworking of the sediments was regionally effective in selective sorting; the more equant minerals (e.g. epidote) and heavier minerals (e.g. opaques) had a higher probability of being selected for permanent deposition during reworking. The process of selective decomposition dominates at the river mouth.

Keywords: heavy minerals, provenance, Piranhas-Açu River
\end{abstract}

INTRODUCTION The study of heavy minerals in sediments was established more than 100 years ago and in spite of the general skepticism towards its value during the middle of this century, the technique has not been neglected. Although many studies of heavy minerals are available to the South, Southeast and North of Brazil (e.g. Tomazelli 1978, Villwock et al. 1979, Wu and Scares 1974, Wu 1981, Stein 1979, Vital et al. 1999), few are found on the Northeast. Moreover, studies of heavy minerals in Northeastern Brazil are concentrated along the coast (e.g. Coutinho and Coimbra 1974) or in the shelf (e.g. Summerhayes et al. 1975, Palma 1979). Only now have studies of heavy minerals along a semi-arid northern river from Brazil been published.

The aim of this paper is to characterize the spatial distribution of heavy mineral associations along the Piranhas-Açu River, which drains a semi-arid hinterland and is the main river of the Rio Grande do Norte State (Northeastern Brazil), trace their provenance, define sediment dispersal patterns, and understand sedimentary processes within the channel of a river of a semi-arid climate.

STUDY AREA The study area is situated in the center-northern portion of the State of Rio Grande do Norte, along the Piranhas-Açu river channel, along about $250 \mathrm{~km}$ between the city of Parelhas and its to the mouth, in the city of Macau (Fig. 1). The hot and dry or semiarid tropical climate prevails in the area, with annual average temperature and rainfall about $27^{\circ} \mathrm{C}$ and $500 \mathrm{~mm}$, respectively. Geomorphologically the study area encompasses the Borborema Plateau, the Sertaneja Depression and the Coastal Plain, as well as alluvial plains, coastal tablelands and the Apodi Plateau.

Most of the hinterland of northeastern Brazil, drained by PiranhasAçu River, exposes crystalline rocks of a Precambrian Shield (Caicó Complex and Seridó Belt: Jucurutu, Equador and Seridó Formations) intruded by granites. Along the coast, the shield is embayed by the Potiguar Basin where Tertiary (Barreiras Formation) and Quaternary (Alluvial covers) sediment, along with Cretaceous strata, crop out (siliciclastic Açu Formation and carbonatic Jandaira Formation). Tertiary magmatic rocks also occur (Fig. 1).

MATERIALS AND METHODS Forty-seven sediment samples were collected along the channel and river margins by bottom-grab at intervals between $5-10 \mathrm{~km}$. Positions of sampling sites were obtained by means of a Global Positioning System (GPS).

Grain-size determinations of the sand fraction were carried out by dry sieving at 1 phi interval. Heavy minerals were separated using Bromoform (density 2,89 g/ $\mathrm{cm}^{3}$ ). Analyses were carried out on the $0,125-0,063 \mathrm{~mm}$ fraction using a petrographic microscope. This fraction was chosen by its abundance of heavy mineral, as compared to other poorer fractions. Heavy mineral proportions were estimated in this fraction by counting at least 300 translucent detrital grains in each mount using the line counting method described by Mange and Maurer (1992). Methods are detailed by Silva (1999).

RESULTS Heavy mineral characterization Many heavy mineral species were recorded along the Piranhas-Acu River, clinoamphibole, epidote (including zoisite), garnet, sillimanite, tourmaline, staurolite, andalusite, zircon, rutile, augite, ilmenite, hematite and magnetite. Major transparent minerals, those forming more than $5 \%$ of some assemblages, are hornblende, epidote, tourmaline, staurolite and zircon. Ilmenite, hematite and magnetite are the major opaque minerals, ilmenite being by large the most abundant. The bulk of heavy minerals in the analyzed fraction varies between $1 \%$ and more than $80 \%$, but in the average $13 \%$.

Heavy mineral distribution The behavior of the heavy minerals along the Piranhas-Açu River is shown in figure 2. The opaque minerals are distributed in significant, yet sporadic amounts along the river. The amount of these minerals increase in the area of the medium course (among 180-150 km) and in the mouth of the river (last $10 \mathrm{~km}$ ) (Fig. 2).

The distribution of the hornblende, in noticeable amounts along the river, indicates a continuous transport in spite of being an unstable mineral (Fig. 2). The smallest values (below 40\%) are found close to the city of Parelhas where the river cuts the aluminous mica schists from the Seridó Formation and locally in the vicinity of São Rafael City and at the mouth of the river.

Epidote is homogeneously distributed along the river, always in inferior amounts up to 5\%. Exceptions are observed between 140 and $110 \mathrm{~km}$, close to São Rafael City, where the values oscillate around $10 \%$, but could reach even more than $20 \%$ between 90 and $75 \mathrm{~km}$ near Açu City. Here, epidote has relatively superior values compared to $5 \%$ (Fig. 2). In the first case, the river cuts paragneiss of the Jucurutu Formation and suites of porphyritic and biotite granites. In the second one, it crosses sandstones from the Açu Formation.

The distribution of the zircon presents the smallest amounts close the City of Parelhas and the largest in the river mouth, around Macau City. Oscillations are observed in these two ends, but toward the mouth, an increasing amount is observed (Fig. 2).

The garnet decreases toward the mouth, reaching values larger than $40 \%$ near the Parelhas City and practically disappearing in the area of Macau (Fig. 2).

The amount of staurolite oscillates along the river. However, there is a tendency to ascending to the lowermost Açu River, when crossing Jandaira Formation limestones and Cenozoic rocks (Fig. 2).

The tourmaline presents values greater than $5 \%$ around the city of Parelhas and in the lowermost Açu River, where it starts to increase progressively toward the mouth, reaching values about $15 \%$. Between the cities of Caicó and Assu it doesn't surpass the 5\% (Fig. 2). The amount of sillimanite is remarkable where the river cuts the aluminous mica schists from Seridó Formation near of Parelhas City, but decreases toward the mouth. The amount of kyanite is small. The andalusite amount oscillates along the river.

Sedimentary processes The presence of heavy minerals in determined studied areas can indicate the mineralogical composition of the source area, but such composition can also be affected by other processes during the sedimentary cycle (Morton 1985) (Fig. 3). Such Processes as: (i) weathering in the area source (previous the incorporation in the transport system), (ii) effects of the transport 
process, (iii) hydraulic conditions in the deposition period and (iv) the diagenetic processes that operate after the deposition (Morton and Johnsson 1993). There are no doubts that during the weathering and the processes of soil formation, the mineralogy of the rock bedding can be strongly altered. In theory, the degree for each one of these occurrences in the area source of the sediments essentially depends on the climate and erosion's rate. The combination of these processes can generate heavy mineral suites that are considerably different when compared with those present in the source rock, and sheds doubt on the reconstruction of the provenance.

To understand the role of each one of the processes (weathering, transport, hydraulic conditions, diagenesis), involved in the generation of heavy mineral assemblages, we must try to isolate the effects of "source" and "processes" as controls of mineral variability. It was used mineral ratios, that are comparatively immune to alterations during the sedimentary cycle (e.g. Flores and Shideler 1978, Vital 1996, Vital et al. 1999, Silva, 1999).

The influence of sediment- grain size on individual heavy minerals, in response to the hydraulic fractionation (Rittenhouse 1943), is minimized in this study by using a limited size range (Morton 1985, Morton and Hallsworth 1994), the very fine sand fractions $(0,063 \mathrm{~mm}$ - $0,125 \mathrm{~mm}$ ). Heavy-mineral ratios were used to examine the difference in the grain shape, density and selective chemical decomposition (Flores and Shiedeler 1978). The shape-fractionation index is expressed by ratios of equant minerals (garnet and epidote) to bladed-elongate minerals (pyroxene + hornblende + tourmaline). The

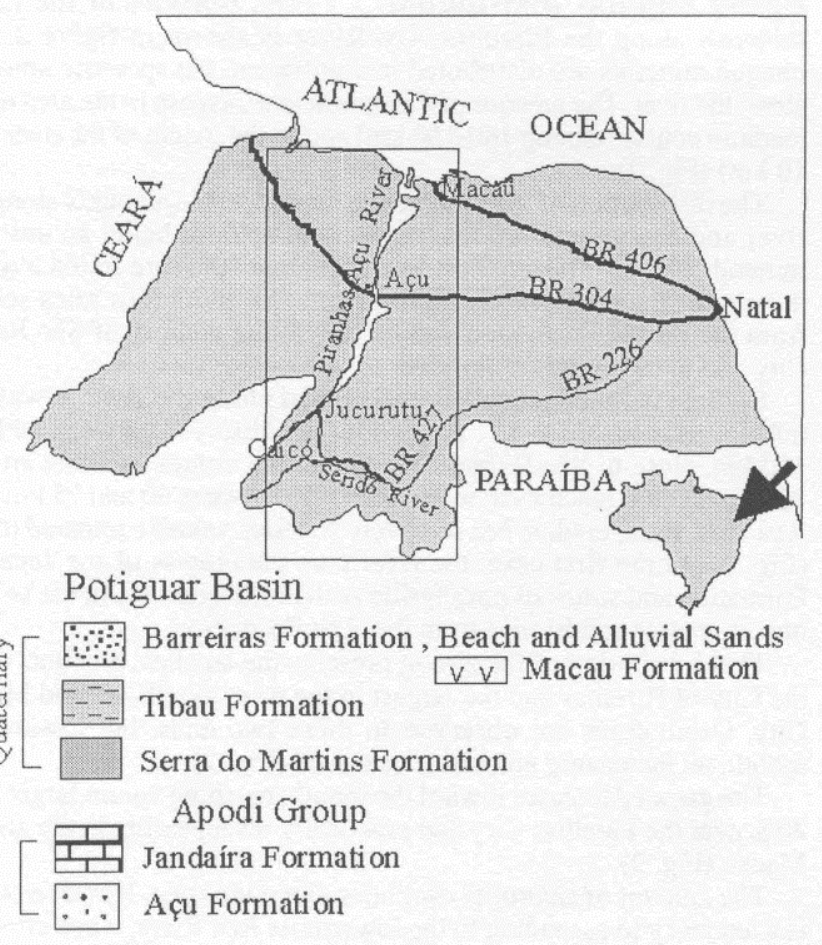

\section{Seridó Belt}

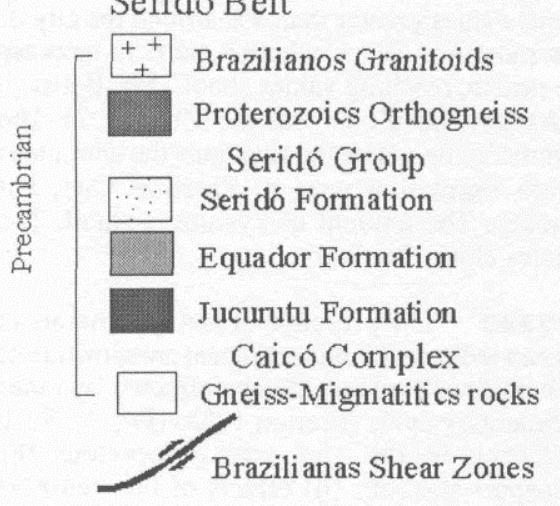

$20 \mathrm{Km}$ ratio used in this study is epidote / (hornblende + tourmaline), hereafter referred to as E/HT. Hydraulic fractionation by density is expressed by the ratio of opaque (ave. sp. gr. $=4.7$ ) minerals to non-opaque (ave. sp. gr. $=3.7$ ), hereafter referred to as $\mathrm{O} / \mathrm{NO}$. The contribution of selective chemical decomposition to heavy mineral variation is inferred from a stability index (zircon + tourmaline + rutile) / (hornblende), hereafter referred to as ZTR/H.

The analyses of these mineral ratios (Fig. 2) show that the selective decomposition (mineral stability), suitable for the index ZTR/H, did not play a significant role in the variation of heavy minerals along the river. This suggests that the process of selective decomposition has acted uniformly along the river. However, at the river mouth, where the coastal processes are active, the selective decomposition is more outstanding. In contrast, limited effects of hydraulic fractionation are observed along the entire river. Hydraulic fractionation largely by shape is suggested by E/HT ratios, which presents significant differences, mainly between 140 and $100 \mathrm{~km}$ (Fig. 2). In the same way, along the river, there is a contribution of the hydraulic fractionation by density $(\mathrm{O} / \mathrm{NO})$. Although significant differences in the $\mathrm{E} / \mathrm{HT}$ and $\mathrm{O} /$ $\mathrm{NO}$ ratios along the river suggest effects of differentiation in the hydraulic fractionation, these differences could also be induced by a provenance factor.

CONCLUSIONS One of the most important aspects of this study is that the mineralogy of the source rocks are comparatively well known. So, the analysis of the heavy mineral distribution along the

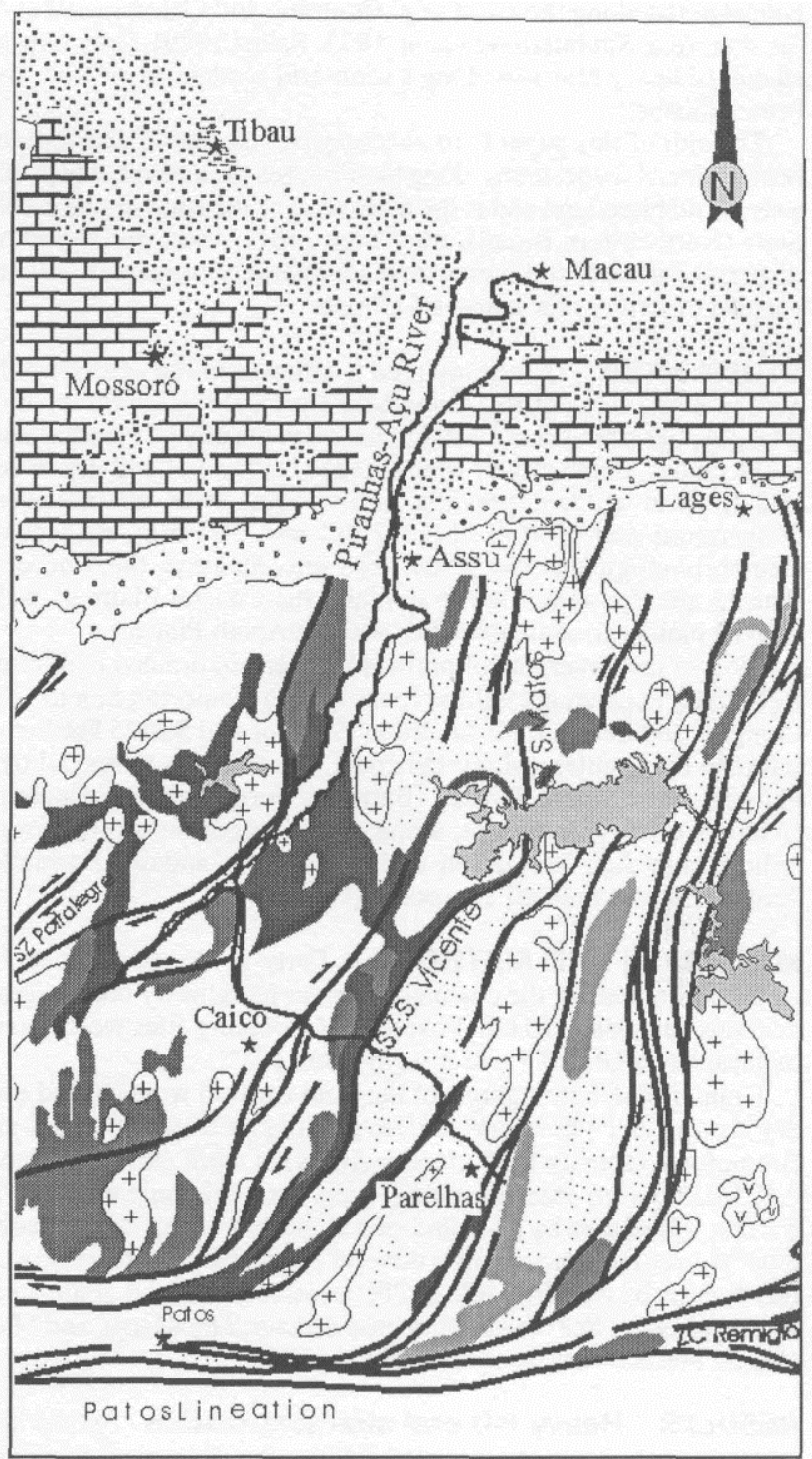




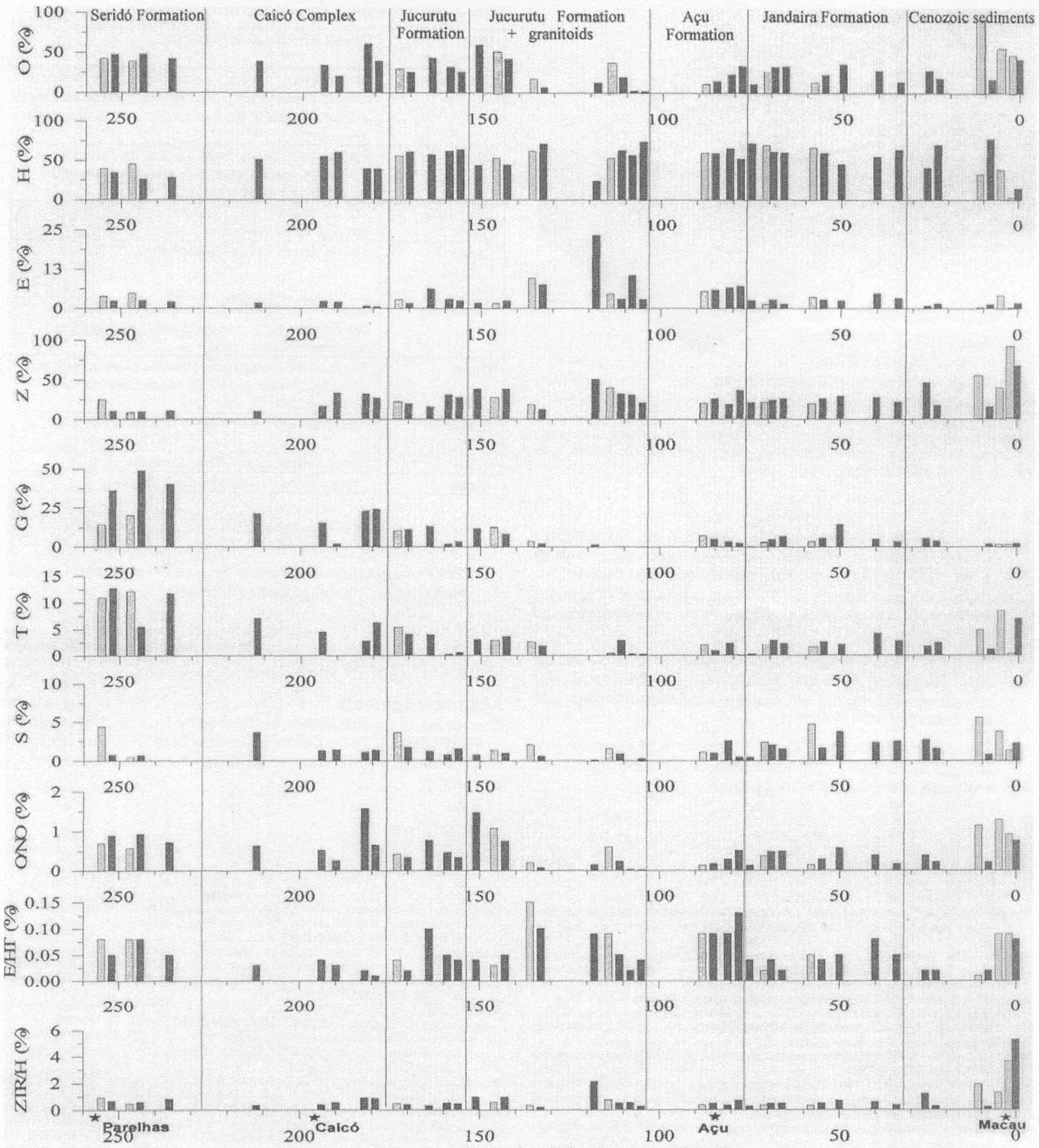

Bar chart symbol: $\square$ channel sample

Figure 2 - Major heavy mineral variations along Piranhas-Açu River. $O$ = opaques; $H$ - hornblende; $E$ - epidote; $Z$ - zircon; $G$ - garnet; $T=$ tourmaline, $S$ - staurolite; $N O=$ non-opaques, $H T=$ hornblende + tourmaline, $Z T R=$ zircon + tourmaline + rutile.

Piranhas-Açu River, associated with previously known information concerning the mineralogy of the crossed units for this river, yielded an understanding in the distinction of six assemblages of heavy minerals as follows:

(i) Garnet-hornblende-tourmaline with sillimanite, when cutting rocks of the Seridó Formation (aluminous mica schists, with variable percentages of garnet, cordierite, staurolite, sillimanite, andalusite and rarely kyanite). This area is near the Queimada
Hill (Equador Formation constituted by quartzites with muscovite, tourmaline \pm sillimanite, and locally rich in epidote \pm garnet).

(ii) Hornblende-garnet-zircon when crossing rocks of the Caico gneiss-migmatite Complex (predominance of tonalitic to granodioritic orthogneisses, and calk-alkaline or subalcaline/ monzonitic granites). 


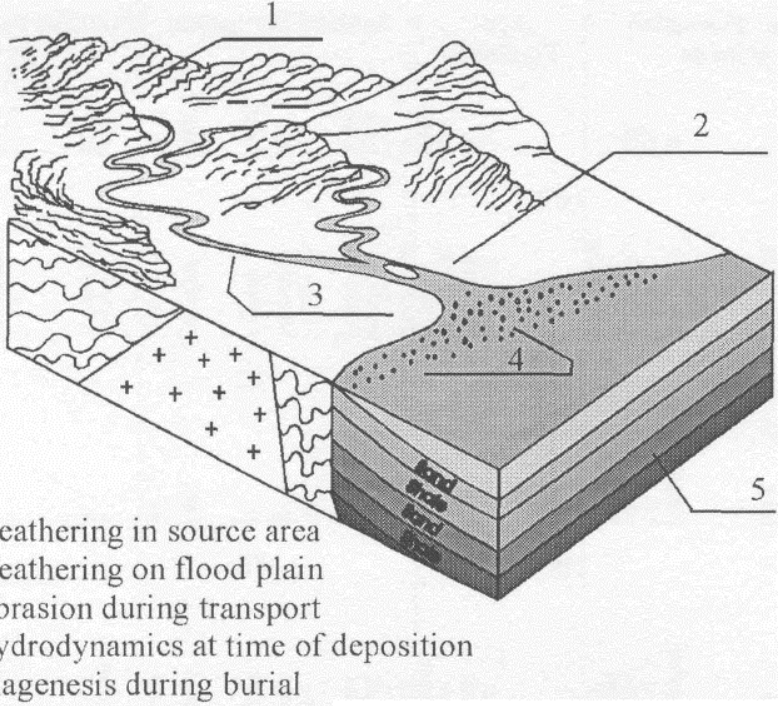

Figure 3 - Schematic illustration of the processes that operate during the sedimentary cycle to overprint the mineralogical signature of the source rocks (modified from Morton 1985).

(iii) Hornblende-zircon-epidote-staurolite when the river cuts the Jucurutu Formation (paragneiss with biotite \pm epidote \pm diopside \pm amphibole. With frequent intercalations of marbles, calcsilicate rocks and paramphibolites), with lateral influence of granites intrusions (biotite-granites, peraluminous or subaluminous, and calk-alkaline suites).

(iv) Hornblende-zircon-epidote-staurolite, when the river crosses the AçU Formation (alluvial sandstones, conglomerates and claystones and fluvial to shallow marine sandstones and claystones). River, when crossing limestones from Jandaira Formation and (v) Hornblende-zircon-staurolite on the lowermost Piranhas-Açu sediments of the Cenozoic rocks.

।

\begin{tabular}{|c|c|}
\hline $\begin{array}{l}\text { HEAVY } \\
\text { MINERAL }\end{array}$ & MOST PROBABLE SOURCE \\
\hline Hornblende & $\begin{array}{l}\text { Micaschists of the Seridó Formation, orthogneiss and } \\
\text { amphibolites of the Caicó Complex, paragneisses and } \\
\text { paramphibolites of the Jucurutu Formation and granite } \\
\text { intrusions }\end{array}$ \\
\hline Epidote & $\begin{array}{l}\text { Paragneiss and calcsilicate rocks of the Jucurutu } \\
\text { Formation, granite intrusions, gravel deposits of the } \\
\text { Açu river and Açu Formation. }\end{array}$ \\
\hline $\begin{array}{l}\text { Sillimanite, } \\
\text { Garnet }\end{array}$ & $\begin{array}{l}\text { Micaschists of the Seridó Formation, quatzites of the } \\
\text { Equador Formation }\end{array}$ \\
\hline $\begin{array}{l}\text { Andalusite, } \\
\text { Kyanite, } \\
\text { Staurolite }\end{array}$ & Micaschists of the Seridó Formation \\
\hline Tourmaline & $\begin{array}{l}\text { Micaschists of the Seridó Formation and quartzites of } \\
\text { the Equador Formation (prismatic), sediments and } \\
\text { sedimentary rocks (round) }\end{array}$ \\
\hline Zircon & $\begin{array}{l}\text { Rocks of the Precambrian Shield in general (pink and } \\
\text { prismatic zircon), sediments and sedimentary rocks } \\
\text { (round zircon) }\end{array}$ \\
\hline $\begin{array}{l}\text { Opaque } \\
\text { minerals }\end{array}$ & All rocks within the Piranhas-Açu River channel \\
\hline Rutile & Seridó Formation and Caicó Complex \\
\hline Augite & Macau, Cuó and Ceará-Mirim Volcanism \\
\hline
\end{tabular}

Table 1 -Heavy minerals and probable source rocks.

Zircon-tourmaline-staurolite in the Açu River mouth (Cenozoic rocks) where coastal processes dominate.

These results allow us to associate each heavy mineral with its most probable source rocks (Table 1).

Acknowledgments

This paper is a part of the Master dissertation of the first author, supervised by $\mathrm{H}$. Vital, and supported by PETROBRAS. To the Geology Department of UFRN for laboratory support and to two referees of RBG for the critical review of the manuscript.

\section{References}

Coutinho J.M.V. \& Coimbra A M. 1974. Os pesados do Barreiras na Costa Oriental Brasileira: Estudo de Areas -Fonte. 28 Cong. Bras. Geol. Porto Alegre, Anais. Vol5, 2741.

Flores R. M. \& Shideler G.L. 1978. Factors controlling heavy-mineral variations on the south Texas outer continental Shelf, Gulf of Mexico. Journal of Sedimentary Petrology. V. 48, p.269-280

Mange M. A. \& Maurer F.W. 1992. Heavy minerals in colour. Chapman \& Hall. 147p.

Menezes M.R.F. 1999. Estudos sedimentologicos e o contexto estrutural da Formação Seira do Martins, nos platos de Portalegre, Martins e Santana/RN. UFRN, Dissertação de mestrado. Natal-RN, 166p + anexos.

Morton A.C. 1985. Heavy minerals in provenance studies. In: G.G.ZUFFA (ed), Provenance of Arenites. P. 249-277.

Morton A.C. \& Johnsson M.J. 1993. Factors influencing the composition of detrital heavy mineral suites in Holocene sands of the Apure River drainage basin, Venezuela. In Geological Society of America, p. 171-185.

Morton A. C. \& Hallsworth C. 1994. Identifying provenance-specific features of detrital heavy mineral assemblages in sandstones. Sedimentary Geology, 90:241-256.

Palma J.C. 1979. Depósitos de minerals pesados. Recursos minerals da margem continental brasileira e das áreas oceânicas adjacentes. Serie Projeto Remac, Nº10, pag. 3350.

Rittenhouse G. R. 1943. Transportation and deposition of heavy minerals: Geological Society of America Bulletin. V.54, p. 1725-1789.

Silva M.G. 1999. Caracterizacão de Minerals Pesados ao longo do rio Piranhas-ACU/RN: Distribuiçãa e proveniência. Universidade Federal do Rio Grande do Norte-UFRN, Dissertação de Mestrado. $71 \mathrm{p}+$ Anexos.

Summerhayes C.P., Coutinho P.N., França, M.C., Ellis J.P. 1975. Salvador to Fortaleza Northeastern Brazil. In: Milliman, J.D. \& Summerhayes C.P. 1975. Upper continental margin sedimentation off Brazil, Contributions to sedimentology. Stuttgart V.4, p. $44-78$
Stein M. M. 1979. Schwermineraluntersuchnngen an Flussproben des Amazonas und seiner wichtigsten Nebenfluesse. Hauptpruefung mineralogie. Institut fuer Sedimentforschung, Heildelberg, F.R.G. 74p.

Tomazelli C.J. 1978. Minerals Pesados da plataforma continental do Rio Grande do Sul. Dissertação de mestrado. Institute de Geociências da Universidade Federal do Rio Grande do Sul. Porto Alegre. Acta Geologica Leopodensia 3 - Estudos Tecnologicos №5. Vol. II - UNISINOS p. $103-160$

Villwock, J.A. Loss E.L., Dehnhardt E.A., Tomazelli L J 1979. Concentraciones de arenes Negras a lo largo de la costa del Rio Grande do Sul (Brasil). In: Memorias del SeNegras a lo largo de la costa del Rio Grande do Sul (Brasil). In: Memorias del Seminario sobre Ecologia Bentonica y Sedimentacion de la Plataforma continental del
Atlantico Sur-Oficina regional de Ciência e Tecnologia de la Unesco para America Atlantico Sur-Oficina regional de Ciência e Tecnologia de la Unesco para America Latina e Caribe, Montevideo, 1979

Vital H. 1996. Sedimentology of the lowermost Amazon (Rio Xingu - Macapá) and the "Estreitos de Breves" - Brazil. Tese de Doutorado. Kiel -Alemanha, 1996. 189p.

Vital H., Statteger K. \& Garbe-schonberg C-D. 1999. Composition and trace-element a provenance study. In: Jour, of sedimentary Research, V.69, $n^{\circ} 3$. p.563-575.

Wu FT. \& Scares P.C. 1974. Minerals pesados nas formações Piramboia e Botucatu - In: XXVIII Cong. Brasil. Geologia. 119-127.

Wu FT. 1981. Minerals pesados das sequências arenosas paleozoica e mesozoica no centro-leste do Estado de Sao Paulo. IG-USP, SP, Dissertação de mestrado. 78p. geochemistry of detrital clay and heavy-mineral suites of the lowermost amazon river:
Contribution IGC-149 Accepted for publication April 27, 2000 Received March 3, 2000 